\title{
Bridge treatment for early cholecystectomy in geriatric patients with acute cholecystitis: Percutaneous cholecystostomy
}

\author{
Sezgin Zeren, M.D., ${ }^{1}$ Zülfü Bayhan, M.D., ${ }^{1}$ Cengiz Koçak, M.D., ${ }^{2}$ Uğur Kesici, M.D., ${ }^{3}$ \\ Mehmet Korkmaz, M.D., ${ }^{4}$ Mehmet Fatih Ekici, M.D., ${ }^{1}$ Mustafa Cem Algın, M.D., ${ }^{1}$ Faik Yaylak, M.D. ${ }^{1}$ \\ ${ }^{1}$ Department of General Surgery, Dumlupınar University Faculty of Medicine, Kütahya-Turkey \\ ${ }^{2}$ Department of Pathology, Dumlupınar University Faculty of Medicine, Kütahya-Turkey \\ ${ }^{3}$ Department of General Surgery, Beykent University Faculty of Medicine, İstanbul-Turkey \\ ${ }^{4}$ Department of Radiology, Dumlupınar University Faculty of Medicine, Kütahya-Turkey
}

\begin{abstract}
BACKGROUND: The main cause of acute cholecystitis (AC) is gallstones, and the incidence of gallstones in elderly patients is high.

METHODS: In this study, we aimed to investigate the efficacy of percutaneous cholecystostomy (PC) before early cholecystectomy in geriatric patients with AC. This retrospective study included 85 patients undergoing laparoscopic or conventional cholecystectomy during early stage of calculous AC.

RESULTS: All patients were over 65 years old and were divided into two groups: Group I, PC plus early cholecystectomy and Group II, only cholecystectomy without PC. Data on age, sex, status of PC before surgery, postoperative complications, postoperative mortality, surgical method, and postoperative hospitalization duration were recorded in our study. The average age in the groups I and II was $75.7 \pm 7.5$ and $73.7 \pm 7.2$ years, respectively, indicating insignificant difference $(p=0.223)$. Although postoperative complication rate was two fold in the non-PC group, the PC plus cholecystectomy group has a few complications $(p=0.032)$. Postoperative mortality was evidently lower in patients who first underwent $P C$ and followed by cholecystectomy $(p=0.017)$. The average hospitalization duration in groups I and II were 5.6 \pm 2.4 days and II.2 \pm 7.7 days, respectively $(\mathrm{p}<0.00 \mathrm{I})$.
\end{abstract}

CONCLUSION: Urgent laparoscopic cholecystectomy is still the best surgical treatment modality for calculous AC. Further, our study results showed that in geriatric patients, bridge treatment, such as PC, can be useful for reducing postoperative complication rates.

Keywords: Acute cholecystitis; bridge treatment; cholecystectomy; percutaneous cholecystostomy; postoperative complication.

\section{INTRODUCTION}

Acute cholecystitis (AC) is known to be an inflammatory status of the gall bladder. Etiology of $A C$ is generally associated with gallstones. ${ }^{[1]}$ Calculous $A C$ is one of the most common disorders leading to admission of patients to emergency department in developed countries. In addition, its incidence is

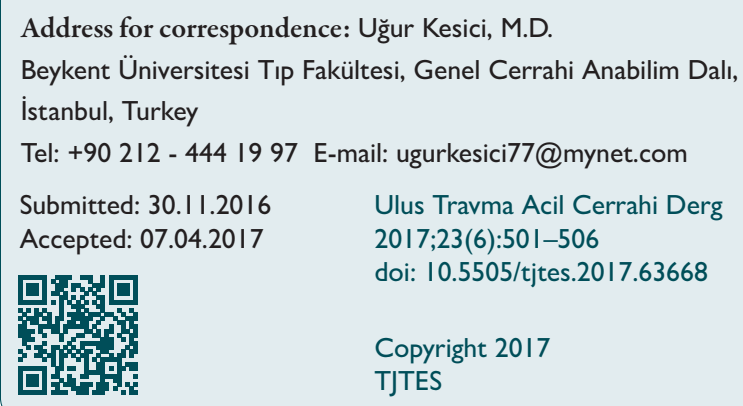

increasing in elderly patients. ${ }^{[2]}$ Human life is getting longer day by day. Therefore, treatment of elderly people has become more important. The patients aged over 65 years are considered as geriatric patients. Especially in cases of geriatric patients, the approach to the treatment of $A C$ varies. ${ }^{[3]}$

To date, the gold standard treatment for AC is laparoscopic cholecystectomy. However, emergency cholecystectomy in geriatric patients with multiple comorbidities may result with high morbidity and mortality rates. ${ }^{[4,5]}$

Percutaneous cholecystostomy (PC) treatment modality has been suggested for geriatric and high-risk patients in recent years. ${ }^{[6]} \mathrm{PC}$ is performed by an experienced surgeon or an interventional radiologist under local anesthesia in critically ill geriatric patients. ${ }^{[7-9]} \mathrm{PC}$ is being preferred as a bridge treatment before cholecystectomy or a definitive non-surgical treatment method for $A C$ in elderly patients. ${ }^{[2,10-12]}$ In the 
majority of the studies, PC was performed initially in AC patients to relieve clinical symptoms, sepsis, and inflammation of the gallbladder. However, only few studies reported any clinical benefit of PC. ${ }^{[13,14]}$

Although the timing of cholecystectomy following PC is still controversial for surgeons, general trend is delayed laparoscopic cholecystectomy (LC). Few studies on early LC after PC have been published. In this study, we investigated the efficacy of PC in geriatric patients and also evaluated the results of early cholecystectomy following PC with many parameters.

\section{MATERIALS AND METHODS}

This retrospective study was performed in the Department of General Surgery of Dumlupinar University Evliyacelebi Training and Research Hospital between March 201I and January 2016. Written informed consent was obtained from all patients. The patients' identities and personal information have not been included in this article.

Data of patients aged over 65 years and who underwent surgery for calculous AC were enrolled. The patients aged under 65 years, having acalculous AC, having obstructive common bile duct stones, and who underwent delayed cholecystectomy were excluded from study. Finally, 85 geriatric patients who had been operated for calculous AC were included, and data on anamnesis, physical examination (Murphy sign positivity), hemogram parameters, biochemical analysis results, C-reactive protein levels, and ultrasonography and computerized tomography scan results were collected. All AC patients were hospitalized. Intravenous antibiotic (cefazolin) and fluid replacement treatments were administered initially. The patients who did not respond to medical treatment in $36 \mathrm{~h}$ directly underwent surgery or PC, followed by cholecystectomy. LC or conventional cholecystectomy was performed I2-72 h later following PC.

Data on age, sex, status of PC before surgery, postoperative complications (bleeding, incision site infection, biliary injuries, deep venous thrombosis, and pulmonary embolism) postoperative mortality, surgical method (laparoscopic or conventional surgery), postoperative hospitalization duration, and comorbidities were recorded.

Subsequently, the patients were divided into two groups. The first group (PC performed group) comprised 40 patients who underwent first ultrasound-guided PC, followed by early LC or conventional cholecystectomy. The second group (no PC group) comprised 45 patients who underwent only early LC or conventional cholecystectomy for AC. We compared early cholecystectomy with or without PC in calculous AC

Table I. Differences in demographic and clinical data between group I and II patients

\begin{tabular}{|c|c|c|c|}
\hline Parameters & $\begin{array}{c}\text { Percutaneous } \\
\text { cholecystostomy }(n=40)\end{array}$ & $\begin{array}{c}\text { No percutaneous } \\
\text { cholecystostomy }(n=45)\end{array}$ & $\begin{array}{c}\text { Statistical analysis } \\
\text { (p) }\end{array}$ \\
\hline Age (years) & $75.7 \pm 7.5$ & $73.7 \pm 7.2$ & 0.223 \\
\hline Gender (n, \%) & & & 0.960 \\
\hline Female & $18(45)$ & $20(44)$ & \\
\hline Male & $22(55)$ & $25(56)$ & \\
\hline Postop complication (n, \%) & & & 0.032 \\
\hline No & $33(83)$ & $27(60)$ & \\
\hline Yes & $7(17)$ & $18(40)$ & \\
\hline Postop mortality (n, \%) & & & 0.017 \\
\hline No & $36(90)$ & $30(67)$ & \\
\hline Yes & $4(10)$ & $15(33)$ & \\
\hline Postop duration of hospitalization (days) & $5.6 \pm 2.4$ & II. $2 \pm 7.7$ & $<0.001$ \\
\hline Surgery type (n, \%) & & & 0.096 \\
\hline Laparoscopic cholecystectomy & $25(63)$ & $20(44)$ & \\
\hline Conventional cholecystectomy & $15(37)$ & $25(56)$ & \\
\hline Convertion to conventional surgery $(\mathrm{n}, \%)$ & $4(10)$ & $9(20)$ & 0.041 \\
\hline Comorbidities (n, \%) & & & 0.833 \\
\hline No & $9(23)$ & II (24) & \\
\hline Yes & 31 (77) & $34(76)$ & \\
\hline
\end{tabular}

Continuous data were presented as mean \pm standard deviation (SD). Categorical data were presented as number ( $n$ ) and percent (\%). Differences in continuous variables between the study groups were analyzed using unpaired t-test. Differences in categorical variables between the study groups were analyzed using Fisher's exact test. A $p$ value of $<0.05$ was considered statistically significant. 
patients. PC was performed transhepatically under local anesthesia by an experienced interventional radiologist team. Surgical methods were chosen by the surgeons. Some LC procedures were converted to conventional cholecystectomy during surgery because of inadequate Callot's area dissection and bleeding.

Statistical analyses were performed using GraphPad Prism version 6.05 (GraphPad Software, Inc., CA, USA). All data sets were tested for normality using Kolmogorov-Smirnov test. Data were presented as mean \pm standard deviation. Categorical data were presented as number (n) and percent (\%). Differences between continuous variables in the study groups were analyzed using unpaired t-test. Differences between categorical variables in the study groups were analyzed using Fisher's exact test. A P value of $<0.05$ was considered statistically significant.

\section{RESULTS}

A total of 85 patients who met the inclusion criteria were enrolled. Patients' sociodemographic characteristics are illustrated in Table I and Figure I. The average age in the first and second groups was $75.7 \pm 7.5$ and $73.7 \pm 7.2$ years, respectively, with no significant differences $(p=0.223)$.

Any morbidities and mortalities were seen in PC. Nevertheless, in one patient, the drainage tube got off from skin came off and did not work. Therefore, PC was performed again. Mortalities occurred due to high-risk status and older age of patients. In the PC plus cholecystectomy group (group I) and the non-PC group (group II), the LC rates were $63 \%$ and $44 \%$, respectively. Same surgical methods were performed in both groups. Notably, the conversion rate from laparoscopic to conventional technique was higher in the non-PC group. The rates of conversion to conventional surgery in groups I and II were $10 \%$ (four patients) and $20 \%$ (nine patients), respectively, with significant difference between the groups $(p=0.041)$. Postoperative complications were bleeding, biliary injury, incision site infection, pulmonary embolism, and deep venous

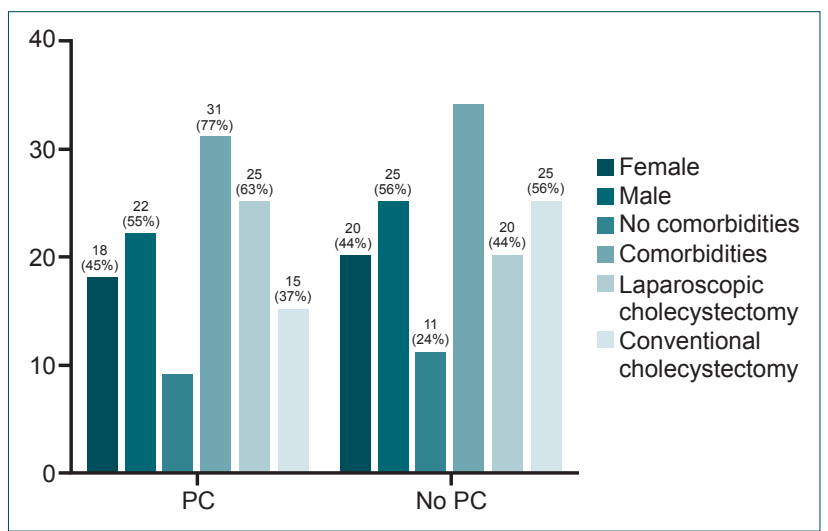

Figure 1. thrombosis. Only in one patient of group I, deep venous thrombosis was detected postoperatively. In both groups pulmonary embolism were detected. The occurrence of other complications was higher in the group II than in group I. Biliary injury and incision site infection were markedly higher in group II than in group I (Fig. 2). Although postoperative complication rate was two fold in group II, group I showed a few complications $(p=0.032)$. Consistent with there findings, postoperative mortality was evidently lower in patients who first underwent PC, followed by cholecystectomy $(p=0.017)$ (Fig. 2). No statistical difference was observed in terms of comorbidities between the groups. Another important parameter assessed was postoperative hospitalization duration. The average hospitalization duration in group I and II was

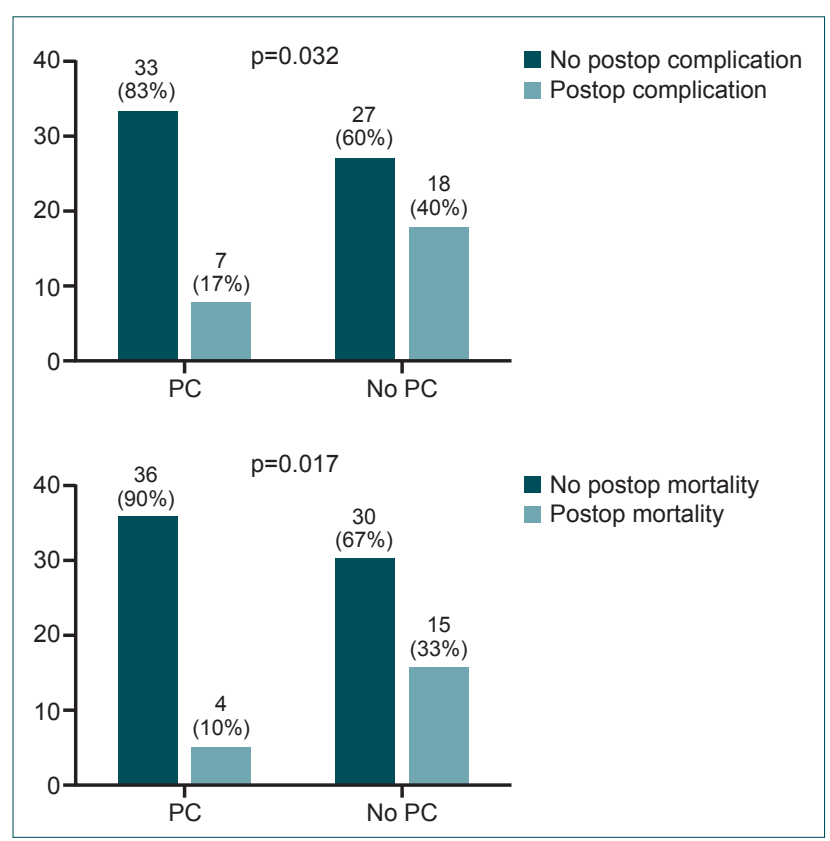

Figure 2. Representative column chart of postoperative complications and mortality of patients in the study groups. PC: Percutaneous cholecystostomy.

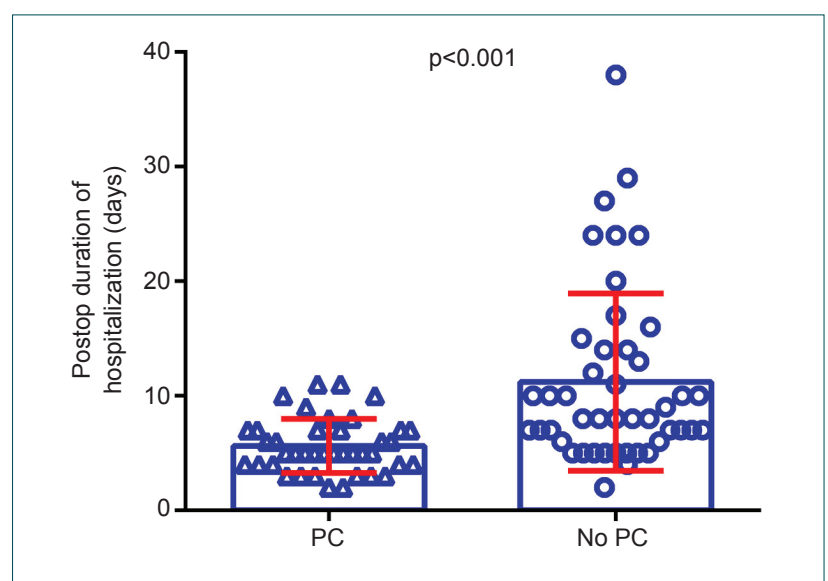

Figure 3. Representative box and whisker plot of postoperative hospitalization duration of patients in the study groups. PC: Percutaneous cholecystostomy. 
$5.6 \pm 2.4$ and II $.2 \pm 7.7$ days, respectively, indicating statistically significant difference with $\mathrm{p}<0.00 \mathrm{I}$, as shown in Table I and Figure 3.

\section{DISCUSSION}

In early stage of AC, LC or conventional cholecystectomy is the first choice of treatment according to Tokyo guidelines. [15] Treating geriatric patients who are unfit for emergency surgery is still a dilemma for surgeons. Although several studies on this subject have been published, an exact consensus for treating high-risk geriatric patients has not been reached. Medical treatment or interventional procedures are favorable in these patients.

$P C$ is an interventional method used in calculous $A C$ commonly as a definitive or bridge treatment modality. It is generally preferred in high-risk and geriatric patients who are unfit for emergency surgery. ${ }^{[7,12,16-19]}$ While in some studies PC procedures were suggested as initial method for AC, only a few studies offer urgent cholecystectomy. ${ }^{[14]}$ In biliary sepsis especially, acute intervention is recommended to remove the focus of infection. Therefore, PC is not inevitable in geriatric and high-risk patients. ${ }^{[20,21]}$

On the other hand, PC is an interventional treatment and is associated with some risks and complications. The rates of complications associated with PC decrease wen Pc is performed by experienced surgeons. However, bleeding, biliary injury, biloma, catheter infection, tube removal from gallbladder, and bowel injury may be observed after PC..$^{[9,16,17]}$ In our study, one patient experienced catheter displacement, and $\mathrm{PC}$ was successfully performed again.

In a recent study, Viste et al. ${ }^{[22]}$ declared that patients who underwent PC had a symptomatic relief with a $96 \%$ rate and a low complication rate. Consistent with these findings, our results suggested that there was a low complication rate in group of patients who underwent PC. In addition, in clinical practice, we observed that patients were relieved within $24 \mathrm{~h}$ after undergoing PC.

In clinical practice, the general approach to treat calculous $A C$ in elderly and high-risk patients is PC. Some physicians have suggested PC in place of LC. However, patients who have $P C$ might have recurrent $A C$ attacks in near future as like as in patients who have nonsurgical treatment modalities. We suggest that PC should be used as a bridge treatment until definitive surgery. ${ }^{[1,13]}$

Another controversy associated with $A C$ is the timing of cholecystectomy after PC. Most researchers perform delayed cholecystectomy. ${ }^{[2]}$ In the literature, a few studies that have investigated early cholecystectomy after PC have been published. Akyürek et al. ${ }^{[23]}$ stated that PC following early cholecystectomy is superior to PC following late cholecystectomy after evaluating early or late cholecystectomy following PC. However, we compared early cholecystectomy following PC with emergency cholecystectomy in geriatric patients.

Li et al. ${ }^{[24]}$ clarified that $P C$ is a viable treatment method with low complication and mortality rates. In addition, in our study, we observed that postoperative complication and mortality rates were lower in patients who underwent PC plus cholecystectomy than in those who underwent cholecystectomy alone.

A systematic review by Ambe et al. ${ }^{[6]}$ revealed that $P C$ is a safe method in critically ill patients. In the present study, the sample comprised geriatric patients with many concomitant chronic diseases. The comorbidities between groups were similar. Complications were markedly lower in the PC plus cholecystectomy group than in the cholecystectomy alone group.

We did not observe catheter-dependent complications in our patients because we performed early cholecystectomy following PC. In terms of other complications, we found that incision site infection and biliary injury was much more common in the cholecystectomy alone group. We believe that the reason behind this was the selection of geriatric patients with chronic diseases as the sample in the study. In addition to this, the rates of complications including biliary injury increase with emergency LC.

Yeo et al. ${ }^{[25]}$ found that in patients with LC following PC, biliary injury rate was lower. In our study, biliary tract injury was two times more common in the non-PC group.

In group II, only one patient had pulmonary embolism and deep venous thrombosis. These results may be due to the concomitant chronic diseases in the geriatric study population.

Furthermore, the rate of conversion to conventional surgery was investigated in our study. Some patients underwent LC or conventional cholecystectomy as per the surgeon's preferences. Karakayali et al. ${ }^{[26]}$ stated that the rate of conversion to open procedure is high in patients undergoing emergency cholecystectomy. The rates of conversion to conventional cholecystectomy in both groups in the present study are similar to those reported in literature. In addition, the rate of conversion from LC to conventional cholecystectomy was higher in that non-PC group than in the PC plus cholecystectomy group.

Therefore, the parameters discussed above affected hospitalization duration and cost-effectivity. A study by Chou et al. ${ }^{[10]}$ and Kapan et al. ${ }^{[27]}$ indicated that patients who underwent PC had decreased hospitalization duration. In this study, we also investigated the postoperative hospitalization duration between the groups and found that patients who underwent 
PC plus cholecystectomy had shorter hospitalization duration than those who underwent cholecystectomy alone. This was because of the lower complication rate in patients who underwent PC. To the best of our knowledge, this is the first study that compared emergency cholecystectomy with urgent cholecystectomy following PC in geriatric patients in terms of postoperative complications and hospitalization duration.

\section{Conclusion}

Calculous AC may result in with serious complications, including sepsis, thus necessitating urgent surgery in geriatric patients. PC should be performed in geriatric patients to reduce postoperative complications, mortality, morbidity, and hospitalization duration. Emergency surgery without PC can lead to high mortality and complication rates.

\section{Conflict of interest: None declared.}

\section{REFERENCES}

1. Wang CH, Wu CY, Yang JC, Lien WC, Wang HP, Liu KL, et al. LongTerm Outcomes of Patients with Acute Cholecystitis after Successful Percutaneous Cholecystostomy Treatment and the Risk Factors for Recurrence: A Decade Experience at a Single Center. PLoS One 2016;11:e0148017. [CrossRef]

2. Mizrahi I, Mazeh H, Yuval JB, Almogy G, Bala M, Simanovski N, et al. Perioperative outcomes of delayed laparoscopic cholecystectomy for acute calculous cholecystitis with and without percutaneous cholecystostomy. Surgery 2015;158:728-35. [CrossRef]

3. Fuks D, Duhaut P, Mauvais F, Pocard M, Haccart V, Paquet JC, et al. A retrospective comparison of older and younger adults undergoing early laparoscopic cholecystectomy for mild to moderate calculous cholecystitis. J Am Geriatr Soc 2015;63:1010-6. [CrossRef]

4. Margiotta SJ Jr, Willis IH, Wallack MK. Cholecystectomy in the elderly. Am Surg 1988;54:34-9. [CrossRef]

5. Pessaux P, Regenet N, Tuech JJ, Rouge C, Bergamaschi R, Arnaud JP. Laparoscopic versus open cholecystectomy: a prospective comparative study in the elderly with acute cholecystitis. Surg Laparosc Endosc Percutan Tech 2001;11:252-5. [CrossRef]

6. McGillicuddy EA, Schuster KM, Barre K, Suarez L, Hall MR, Kaml GJ, et al. Non-operative management of acute cholecystitis in the elderly. $\mathrm{Br} \mathrm{J}$ Surg 2012;99:1254-61. [CrossRef]

7. Howard JM, Hanly AM, Keogan M, Ryan M, Reynolds JV. Percutaneous cholecystostomy-a safe option in the management of acute biliary sepsis in the elderly. Int J Surg 2009;7:94-9. [CrossRef]

8. Winbladh A, Gullstrand P, Svanvik J, Sandström P. Systematic review of cholecystostomy as a treatment option in acute cholecystitis. HPB (Oxford) 2009;11:183-93. [CrossRef]

9. Silberfein EJ, Zhou W, Kougias P, El Sayed HF, Huynh TT, Albo D, et al. Percutaneous cholecystostomy for acute cholecystitis in high-risk patients: experience of a surgeon-initiated interventional program. Am J Surg 2007;194:672-7. [CrossRef]

10. Chou CK, Lee KC, Chan CC, Perng CL, Chen CK, Fang WL, et al. Early Percutaneous Cholecystostomy in Severe Acute Cholecystitis Reduces the Complication Rate and Duration of Hospital Stay. Medicine (Baltimore) 2015;94:e1096. [CrossRef]

11. Patel PP, Daly SC, Velasco JM. Training vs practice: A tale of opposition in acute cholecystitis. World J Hepatol 2015;7:2470-3. [CrossRef]

12. Popowicz A, Lundell L, Gerber P, Gustafsson U, Pieniowski E, Sinabulya $\mathrm{H}$, et al. Cholecystostomy as Bridge to Surgery and as Definitive Treatment or Acute Cholecystectomy in Patients with Acute Cholecystitis. Gastroenterol Res Pract 2016;2016:3672416. [CrossRef]

13. Cheng WC, Chiu YC, Chuang CH, Chen CY. Assessing clinical outcomes of patients with acute calculous cholecystitis in addition to the Tokyo grading: a retrospective study. Kaohsiung J Med Sci 2014;30:45965. [CrossRef]

14. Anderson JE, Inui T, Talamini MA, Chang DC. Cholecystostomy offers no survival benefit in patients with acute acalculous cholecystitis and severe sepsis and shock. J Surg Res 2014;190:517-21. [CrossRef]

15. Mayumi T, Takada T, Kawarada Y, Nimura Y, Yoshida M, Sekimoto M, et al. Results of the Tokyo Consensus Meeting Tokyo Guidelines.J Hepatobiliary Pancreat Surg 2007;14:114-21. [CrossRef]

16. Ambe PC, Kaptanis S, Papadakis M, Weber SA, Zirngibl H. Cholecystectomy vs. percutaneous cholecystostomy for the management of critically ill patients with acute cholecystitis: a protocol for a systematic review. Syst Rev 2015;4:77. [CrossRef]

17. Hadas-Halpern I, Patlas M, Knizhnik M, Zaghal I, Fisher D. Percutaneous cholecystostomy in the management of acute cholecystitis. Isr Med Assoc J 2003;5:170-1.

18. Bala M, Mizrahi I, Mazeh H, Yuval J, Eid A, Almogy G. Percutaneous cholecystostomy is safe and effective option for acute calculous cholecystitis in select group of high-risk patients. Eur J Trauma Emerg Surg 2016;42:761-6. [CrossRef]

19. Cha BH, Song HH, Kim YN, Jeon WJ, Lee SJ, Kim JD, et al. Percutaneous cholecystostomy is appropriate as definitive treatment for acute cholecystitis in critically ill patients: a single center, cross-sectional study. Korean J Gastroenterol 2014;63:32-8. [CrossRef]

20. Al-Jundi W, Cannon T, Antakia R, Anoop U, Balamurugan R, Everitt N, et al. Percutaneous cholecystostomy as an alternative to cholecystectomy in high risk patients with biliary sepsis: a district general hospital experience. Ann R Coll Surg Engl 2012;94:99-101. [CrossRef]

21. Horn T, Christensen SD, Kirkegård J, Larsen LP, Knudsen AR, Mortensen FV. Percutaneous cholecystostomy is an effective treatment option for acute calculous cholecystitis: a 10-year experience. HPB (Oxford) 2015;17:326-31. [CrossRef]

22. Viste A, Jensen D, Angelsen J, Hoem D. Percutaneous cholecystostomy in acute cholecystitis; a retrospective analysis of a large series of $104 \mathrm{pa}-$ tients. BMC Surg 2015;15:17. [CrossRef]

23. Akyürek N, Salman B, Yüksel O, Tezcaner T, Irkörücü O, Yücel C, et al. Management of acute calculous cholecystitis in high-risk patients: percutaneous cholecystotomy followed by early laparoscopic cholecystectomy. Surg Laparosc Endosc Percutan Tech 2005;15:315-20. [CrossRef]

24. Li JC, Lee DW, Lai CW, Li AC, Chu DW, Chan AC. Percutaneous cholecystostomy for the treatment of acute cholecystitis in the critically ill and elderly. Hong Kong Med J 2004;10:389-93.

25. Yeo CS, Tay VW, Low JK, Woon WW, Punamiya SJ, Shelat VG. Outcomes of percutaneous cholecystostomy and predictors of eventual cholecystectomy. J Hepatobiliary Pancreat Sci 2016;23:65-73. [CrossRef]

26. Karakayali FY, Akdur A, Kirnap M, Harman A, Ekici Y, Moray G. Emergency cholecystectomy vs percutaneous cholecystostomy plus delayed cholecystectomy for patients with acute cholecystitis. Hepatobiliary Pancreat Dis Int 2014;13:316-22. [CrossRef]

27. Kapan M, Onder A, Tekbas G, Gul M, Aliosmanoglu I, Arikanoglu Z, et al. Percutaneous cholecystostomy in high-risk elderly patients with acute cholecystitis: a lifesaving option. Am J Hosp Palliat Care 2013;30:16771. [CrossRef] 
ORİJINAL ÇALIŞMA - ÖZET

\title{
Akut kolesistitli yaşlı hastalarda erken kolesistektomi için köprü tedavisi: Perkütan kolesistostomi
}

\author{
Dr. Sezgin Zeren, ${ }^{1}$ Dr. Zülfü Bayhan, ${ }^{1}$ Dr. Cengiz Koçak, ${ }^{2}$ Dr. Uğur Kesici, ${ }^{3}$ Dr. Mehmet Korkmaz, ${ }^{4}$ \\ Dr. Mehmet Fatih Ekici, ${ }^{1}$ Dr. Mustafa Cem Algın, ${ }^{1}$ Dr. Faik Yaylak ${ }^{1}$
}

${ }^{1}$ Dumlupınar Üniversitesi Tıp Fakültesi, Genel Cerrahi Anabilim Dalı, Kütahya

${ }^{2}$ Dumlupınar Üniversitesi Tıp Fakültesi, Patoloji Anabilim Dalı, Kütahya

${ }^{3}$ Beykent Üniversitesi Tıp Fakültesi, Genel Cerrahi Anabilim Dalı, İstanbul

${ }^{4}$ Dumlupınar Üniversitesi Tıp Fakültesi, Radyoloji Anabilim Dalı, Kütahya

AMAÇ: Akut kolesistitin (AC) başlıca sebebi safra taşlarıdır. Yaşııı hastalarda safra taşı insidansı artmaktadır. Bu çalışmada, akut kolesistitli yaşlı hastalarda erken kolesistektomi öncesi perkütan kolesistostominin (PK) etkinliğinin araştırılması amaçlandı.

GEREÇ VE YÖNTEM: Bu geriye dönük çalışma konvansiyonel veya laparoskopik kolesistektomiye (LC) giden 85 erken evre akut taşlı kolesistitli hasta içermektedir. Tüm hastalar 65 yaş üzerindedir.

BULGULAR: Hastalar iki gruba ayrıldı. Grup I; PK+erken kolesistektomi ve Grup Il; yalnızca kolesistektomi. Çalısmamızda yaş, cinsiyet, cerrahi öncesi PK durumu, ameliyat sonrası komplikasyon, ameliyat sonrası mortalite, cerrahi yöntem ve ameliyat sonrası hastanede kalıs süresi kaydedildi. Ortalama yaş $75.7 \pm 7.5$ ve $73.7 \pm 7.2$ idi. İki grup arasında anlamlı fark yoktu $(p=0.04 \mathrm{I})$. Ameliyat sonrası komplikasyon oranı PK uygulanmayan grupta iki kat iken, PK ile kolesistektomi yapılan grupta az komplikasyon mevcuttu $(\mathrm{p}=0.032)$. Ameliyat sonrası mortalite bariz şekilde PK sonrası kolesistektomi uygulanan hastalarda düşüktü $(p=0.017)$. Ortalama hastane yatış süresi grup l'de $5.6 \pm 2.4$ gün ve Grup 2'de II.2 \pm 7.7 gündü ( $p<0.00$ I). TARTIŞMA: Akut taşlı kolesistitte acil laparoskopik kolesistektomi hala en iyi cerrahi yöntemdir. Ayrıca çalısmamıza göre, geriatrik hastalarda perkütan kolesistostomi geçiş tedavisi ameliyat sonrası komplikasyon oranlarını azaltmada faydalı olabilir.

Anahtar sözcükler: Akut kolesistit; erken cerrahi; geriatrik; hastanede kalıs; kolesistektomi; perkütan kolesistostomi.

Ulus Travma Acil Cerrahi Derg 2017;23(6):50I-506 doi: 10.5505/tjtes.2017.63668 